\title{
Analisis Budaya Organisasi dan Gaya Komunikasi Karyawan (Studi Kasus pada PT. XYZ)
}

\author{
Adisty Nurkumala ${ }^{\varpi}$, Alda Amelia Majid ${ }^{2}$, Dedi Raianto Rahadi ${ }^{3}$ \\ 1,2,3, Program Studi Manajemen, President University, Cikarang Utara, Indonesia
}

\begin{abstract}
ABSTRAK
Pada sebuah perusahaan budaya organisasi merupakan sebuah alat atau sarana yang memiliki fungsi sebagai sarana dalam peningkatan dan sebagai pedoman bagi sebuah perusahaan serta merupakan nilai-nilai yang diterapkan oleh karyawan dalam berperilaku dan melaksanakan komunikasi dalam pelaksanaan aktivitas sehari-hari, hal tersebut juga berlaku pada PT. XYZ. Namun nyatanya yang terjadi pada PT. XYZ dapat disamakan dengan hal tersebut dimana sesuai dengan observasi sebelumnya yang telah dilakukan oleh peneliti ditemukan bahwa sering terjadi miss komunikasi dalam pelaksanaan tugas dan tanggung jawab pegawai. Sehingga dengan adanya hal tersebut banyak pekerjaan karyawan yang tidak selesai tepat waktu dan terdapat pekerjaan rangkap yang dilakukan oleh karyawan karena kurangnya kerjasama tim. Sehingga perlu dilakukan penelitian untuk menganalisis hubungan budaya organisasi terhadap komunikasi karyawan pada PT. XYZ. Metode yang dipergunakan dalam penelitian ini yaitu jenis penelitian kualitatif deskriptif dengan informan yang dipergunakan dalam penelitian ini adalah karywan yang bekerja pada PT. XYZ yang berjumlah 5 Orang. Hasil Penelitian yang didapatkan dalam penelitian ini adalah bahwasannya komunikasi yang berlangsung pada karyawan yang bekerja pada PT. XYZ dibentuk oleh budaya organisasi yang diterapkan oleh PT. XYZ yaitu budaya kolektif yang berorientasi pada kerjasama tim, budaya tidak adanya sistem atasan dan bawahan serta budaya anggapan satu perusahaan seumur hidup.
\end{abstract}

Kata-kunci:

Budaya Organisasi, Komunikasi Organisasi, Kinerja Karyawan

Abstract : At a company organizational culture is a tool or means that has a function as
a means of improvement and as a guide for a company and is the values applied by
employees in behaving and carrying out communication in carrying out daily activities,
this also applies to PT. XYZ. But in fact what happened to PT. XYZ can be likened to this
where in accordance with previous observations made by researchers it was found that
there was often a miss of communication in carrying out employee duties and
responsibilities. So that with this there are many employee jobs that are not completed
on time and there are duplicate jobs carried out by employees due to lack of teamwork.
So it is necessary to do research to analyze the relationship between organizational
culture and employee communication at PT. XYZ. The method used in this research is
descriptive qualitative research with the informants used in this study are employees 
who work at PT. XYZ, amounting to 5 people. Research results obtained in this study is that the communication that takes place on employees who work at PT. XYZ was formed by the organizational culture applied by PT. XYZ is a collective culture that is oriented towards teamwork, a culture of the absence of a superior and subordinate system and a culture of one company for a lifetime.

Keywords : Organizational Culture, Organizational Communication, Employeeperformance

$\triangle$ Corresponding author:

Email Address : adisty.nurkumala@president.ac.id

"Received 12, Agustus 2020, Accepted 15, Januari 2021, Published 07, Februari 2021"

\section{Pendahuluan}

\section{Budaya Organisasi}

Budaya organisasi yaitu sebuah aturan yang diterapkan oleh sebuah organisasi atau perusahaan dalam melakukan kegiatan operasionalnya yang merupakan bentuk hasil dari adanya struktur atau kestrukturan yang ada pada organisasi atau perusahaan maupun fungsi yang dijalankan oleh setiap anggota atau karyawan perusahaan, baik itu dalam organisasi yang terdesentralisasi maupun organisasi yang menganut sistem sentralisasi(Awadh dan Saad, 2013). Selain itu budaya organisasi juga dapat dikatakan sebagai sebuah hasil dari sikap maupun perilaku yang dilaksanakan oleh anggota maupun karyawan dalam melaksanakan setiap pekerjaan yang jadi tanggung jawabnya ataupun dengan kata lain ialah suatu prilaku psikologis antara anggota organisasi dengan organisasinya atau perusahaan tempat mereka bekerja. Setiap budaya organisasi yang diterapkan oleh setiap perusahaan akan berbeda dengan perusahaan lainnya karena hal tersebut tidak mungkin sama karena setiap individu memiliki karakteristik masing-masing dan juga memiliki ciri khas masing-masing dalam melaksanaka tanggung jawabnya (Sari, 2013).

Budaya organisasi yang ada pada perusahaan akan memberikan pengaruh kepada setiap perilaku dan tindakan karyawan atau anggota sebuah organisasi atau perusahaan dalam menjalankan kegiatan sehari-hari mereka dalam lingkup organisasi atau perusahaan(Rizza Muhammad, 2013). Sehingga dengan adanya budaya organisasi nantinya akan menciptakan lingkungan atau kondisi lingkungan kerja baik itu bersifat membangun 
maupun yang bersifat tidak membagun, hal tersebut nantinya akan mempengaruhi kinerja dan tingkat keamanan yang dirasakan oleh karyawan atau anggota organisasi dalam melaksanakan dan menjalankan setiap tugasnya.Maka dari itu budaya organisasi merupakan pandangan maupun asumsi yang didasarkan pada pandangan bersama yang kemudian dipahami oleh setiap individu maupun anggota organisasi atau perusahaan yang nantiya dipergunakan dalammencari solusi dari setiap permasalahan maupun kendala-kendala yang ada pada setiap pekerjaan yang dilakukan. Hal tersebut dilakukan turun temurun dan diperkenalkan kepada setiap anggota baru yang bergabung pada perusahaan atau organisasi agar nantinya dapat menyelesaikan setiap permasalahan yang terjadi dalam menjalankan kegiatan operasional persahaan (Dewi, 2012).

Didasarkan pada beberapa pengertian budaya organisasi tersebut maka yang dimaksud dengam budaya organisasi pada penelitian ini adalah suatu nilai maupun norma serta perilaku yang diterapkan dalam menjalankan kegiatan operasional perusahaan atau organisasi yang lahir dari setiap perilaku yang dilakukan oleh anggota atau karyawan dalam menyelesaikan setiap tanggung jawab maupun tugas yang sudah menjadi tanggung jawabnya yang diwariskan secara turun temurun yang dipergunakan dalam penyelesaian setiap permasalahan yang dihadapi pada pelaksanaan tugas dan tanggung jawabnya pada perusahaan atau organisasi. Aggota atau karyawan dari sebuah perusahaan atau organisasi harus memiliki kemampuan untuk mencerna serta memahami setiap budaya organisasi yang diterapkan oleh perusahaan baik itu dari ciri khas yang dimiliki oleh perusahaan maupun karakteristik lainnya sehingga dapat menunjang keberlangsungan komunikasi yang baik dan dapat meningkatkan kinerja anggota atau karyawan.Hal tersebut nantinya dapat memeberikan kenyamanan dan ketepatan pada pelaksanaan setiap tanggung jawab anggota atau karyawan pada perusahaan. Adapun yang menjadi ukuran atau indikator dalam pelaksanaan penelitian ini pada pembahasan budaya organisasi yaitu karakteristik yang dimiliki oleh budaya organisasi yang didasarkan pada indikator dari Robbins dan Judge, Dimana hal itu di perkuat oleh penelitian yang telah dilakukan sebelumnya dimana juga mempergunakan indikator karakteristik dari budaya organisasi yang dipergunakan oleh sebuah perusahaan maupun organisasi. 


\section{Komunikasi Organisasi}

Komunikasi adalah sebuah arahan atau pedoman maupun interaksi yang dilakukan oleh dua orang ataupun lebih yang merupakan suatu tafsiran terhadap suatu pesan yang hendak mau di informasikan kepada seseorang yang merupakan bagian dari sebuah perusahaan(Nia Septiana, 2014). Komunikasi yang baik jika terjalin dengan baik dan terarah pada anggota organisasi atau karyawan perusahaan akan menghasilkan sebuah kerja sama yang baik dalam perusahaan. Namun jika proses komunikasi antar karyawan memiliki kualitas yang buruk maka kerja sama yang terjadi antar karyawan atau anggota organisasi akan buruk karena akan sering mengalami kesalahfahaman dalam informasi yang disampaikan sehingga akan mengganggu keterlaksanaan tanggung jawab yang dimiliki. Suatu komunikasi juga akan memberikan pengaruh terhadap pelaksanaan pekerjaan yang efisien dan efektif serta dalam keterbaruan semangat yang ada pada setiap anggota organisasi atau karyawan pada perusahaan sehingga nantinya dapat meraih kinerja yang baik dalam pelaksanaan tugas dan memunculkan kekreatifan dan keinovatifan pada setiap karyawan maupun anggota organisasi dalam menjalankan tugas serta tanggung jawabnya (Prabawa, 2013).

Dari penjelasan di atas maka yang dimaksud degan komunikasi dalam penelitian ini adalah sebuah interaksi yang dilakukan antar anggota maupun karyawan untuk menunjang pelaksanaan tugas yang dilakukan, karena tanpa adanya sebuah komunikasi yang baik antar karyawan tidak akan mehasilkan keefektifan dan keefisienan dalam pelaksanaan pekerjaan yang menjadi tanggung jawab masing-masing karyawan perusahaan. Sehingga pesan yang hendak ingin disampaiakan tidak sampai dengan jelas dan tidak dapat dimengerti serta dicerna sehigga sering menimbulkan kesalahfahaman dalam pelaksanaan kerja.

Komunikasi yang ada pada perusahaan memiliki beberapa jenis yaitu yang pertama adalah komunikasi vertical dari atas kebawah, jenis komunikasi ini merupakan sebuah komunikasi yang dilaksanakan atau dijalankan dengan pesan atau informasi yang berasal dari atasan yang memiliki jabatan yang paling tinggi sampai ke bawahan yang memiliki jabatan yang paling rendah dalam struktur organisasi. Biasanya bentuk informasi atau 
pesan yang hendak disampaikan berbentuk pelaksanaan dari kegiatan kerja yang menjadi tanggung jawab masing-masing dalam organisasi atau perusahaan.Menurut Nia Septiana (2014) tipe-tipe instruksi yang dimiliki oleh jenis komunikasi ini adalah:

a. Tugas dimana hal tersebut dinyatakan atau diinstruksikan sebagai bentuk pesan yang hendak ingin disampaiakan dari atasan yang ditujukan pada bawahanyang mencakup apa yang semestinya dilakukan dan bagaimana cara dari pelaksanaannya.

b. Rasional merupakan intruksi dari sebuah pekerjaan yang dilaksanakan berupa pesan atau informasi yang memberikan penjelsan terkait dengan tujuan dari kegiatan maupun keterkaitan antara kegiatan yang dilakukan dengan kegiatan lainnya dalam sebuah organisasi.

c. Idiologi merupakan instruksi dari sebuah pekerjaan yang merupakan penjabaran dari sebuah informasi atau pesan yang disampaikan dimana hal tersebut memberikan penekanan pada penjabaran secara detail dari tugas dan keterkaitannya dengan sudut pandanf organisasi sehigga mmberikan loyalitas atau keloyalan pada karyawan maupun anggota organisasi yang dapat berupa motivasi dan sebagainya.

d. Informasi yang dimaksudkan merupakan proses perkenalan bawahan dengan kegiatan maupun aktivitas pekerjaan yang ada pada organisasi baik itu peraturan yang berlaku pada organisasi maupun profit yang ingin dicapai serta kebiasaan-keiasaan yang sering dijalankan dalam organisasi tersebut dengan tujuan untuk mencapai tujuan organisasi yang sebelumnya telah ditetapkan.

e. Balikan merupakan sebuah informasi atau pesan yang bertujuan untuk menginformasikan terkait ketepatan atau kesesuaian anggota atau karyawan dalam melakukan tugas serta tanggung jawab yang telah dibebankan kepadanya.

Komunikasi yang bersifat vertikal dari bawah ke atas dimana jenis komunikasi ini lebih cenderung pada bagaimana cara seorang bawahan memberikan respon terhadap peraturan maupun kebijakan yang berlaku pada organsasi atau perusahaan(Akbar, 2015). Sehingga nantinya dengan adanya hal tersebut atasan dapat melihat bagaimana input yang diberikan oleh seorang karyawan sehingga nantinya dapat memberikan dukungan terhada proses pengambilan keputusan yang dilakukan oleh atasan dalam proses penyelesian setiap pekerjaan yang ada pada perusahaan. Sehingga dengan adanya hal tersebut bawahan maupun pimpinan dapat bekerja dan melaksanakan tugasnya secara optimal dan 
efektif serta efisien. Sehingga nantinya setiap proses pengambilan keputusan yang dilakukan oleh atasan dapat dilakukan dengan tepat melaui pertimbangan-pertimbangan yang tepat dan jelas. Komunikasi tersebut bertujuan untuk memberkan respon terhada suatu hal atau masalah yang terjadi pada organisasi.

Komunikasi Horizontal, tipe komunikasi jenis ini adalah biasanya lebih menekankan pada menyampaikan pesan atau informasi yang ditujuan pada karyawan yang ada pada satu dapartemen atau satu level, biasanya terjadi pada antar anggota atau karyawan perusahaan. Dimana organisasi ini bertujuan untuk memberikan kelancaran pada pelaksanaan kegiatan organisasi atau perusahaan dalam pelaksanaan tugas-tugas yang dilakukan.Sehingga dengan adanya hal tersebut dapat membantu penyelesaian setiap masalah yang ada pada pelaksanaan pekerjaan antar karyawan dan mencegah terjadinya miss komunikasi atau kesalahan informasi antar sesama anggota perusahaan sehingga dapat bekerja sama dengan baik (Akbar, 2015). Setiap perusahaan membutuhkan karyawan yang memiliki tingkat komunikasi yang baik dalam pelaksanaan setiap tugasnya.Baik itu komunikasi yang dilakukan antar sesama rekan kerja maupun komunikasi yang dilakukan dengan pimpinan sehingga nantinya dalam pelaksanaan setiap tanggung jawab yang telah dibebankan atau job desk masing-masing dapat berjalan dengan baik, tanpa adanya keslahfahaman dalam penerimaan maupun penyampaian informasi.Oleh karena itu budaya organisasi juga sangat menentukan dari komunikasi yang dilakukan oleh setiap anggota organisasi atau perusahaan.Karena hal tersebut juga dipengaruhi oleh kebiasaan-kebiasaan yang dilakukan atau dijalankan oleh setiap anggota organisasi dalam setiap pelaksanaan tugas dan tanggung jawab mereka.

\section{Metode Penelitian}

Pelaksanaan dari penelitian ini mepergunakan jenis penelitian dengan metode penelitian kualitatif deskriptif. Dengan penggunaan informan sebanyak 5 orang karyawan yang bekerja pada PT. XYZ. Teknik pengumpulan data yang dipergunakan pada penerapan penelitian ini ialah dengan teknik wawancara mendalam, observasi partisipan, diskusi kelompok terarah, serta analisis dokumen. Sedangkan itu, instrumen yang peneliti 
gunakan adalah kuisioner terbuka ataupun pedoman wawancara tidak terstruktur ataupun terdapat pula yang hanya menggunakan catatan-catatan khusus dari peristiwa.

Tabel 1. Pertanyaan Wawancara

\begin{tabular}{|c|c|}
\hline Variabel & Pertanyaan \\
\hline \multirow[t]{3}{*}{$\begin{array}{l}\text { Budaya } \\
\text { Organisasi }\end{array}$} & $\begin{array}{l}\text { Apakah karyawan PT. XYZ menerapkan budaya kolektif yang berorientasi } \\
\text { kepada kerjasama tim? }\end{array}$ \\
\hline & $\begin{array}{l}\text { Jika timbul permasalahan di tempat kerja selalu diselesaikan bersama- } \\
\text { sama. }\end{array}$ \\
\hline & $\begin{array}{l}\text { Setiap bekerja saya lebih mengutamakan terhadap pelayanan umum dari } \\
\text { pada kepentingan pribadi/kelompok. }\end{array}$ \\
\hline \multirow{5}{*}{$\begin{array}{l}\text { Gaya } \\
\text { Komunikasi }\end{array}$} & Apakah ada sistem atasan dan bawahan yang kental pada perusahaan? \\
\hline & $\begin{array}{l}\text { Mampu membina hubungan yang baik dengan karyawan baik dalam } \\
\text { konteks } \\
\text { pribadi maupun dalam lingkup hubungan kerja. }\end{array}$ \\
\hline & Pimpinan saya selalu mendengarkan pendapat bawahannya. \\
\hline & $\begin{array}{l}\text { Apakah Budaya Organisasi yang diterapkan oleh PT. XYZ memperlancar } \\
\text { proses Komunikasi antar karyawan? }\end{array}$ \\
\hline & $\begin{array}{l}\text { Apakah Budaya organisasi yang diterapkan oleh PT. XYZ dapat } \\
\text { membentuk komunikasi yang baik dengan karyawan maupun pimpinan } \\
\text { PT. XYZ? }\end{array}$ \\
\hline
\end{tabular}

\section{Hasil Penelitian}

Tabel 2. Jawaban Hasil Wawancara

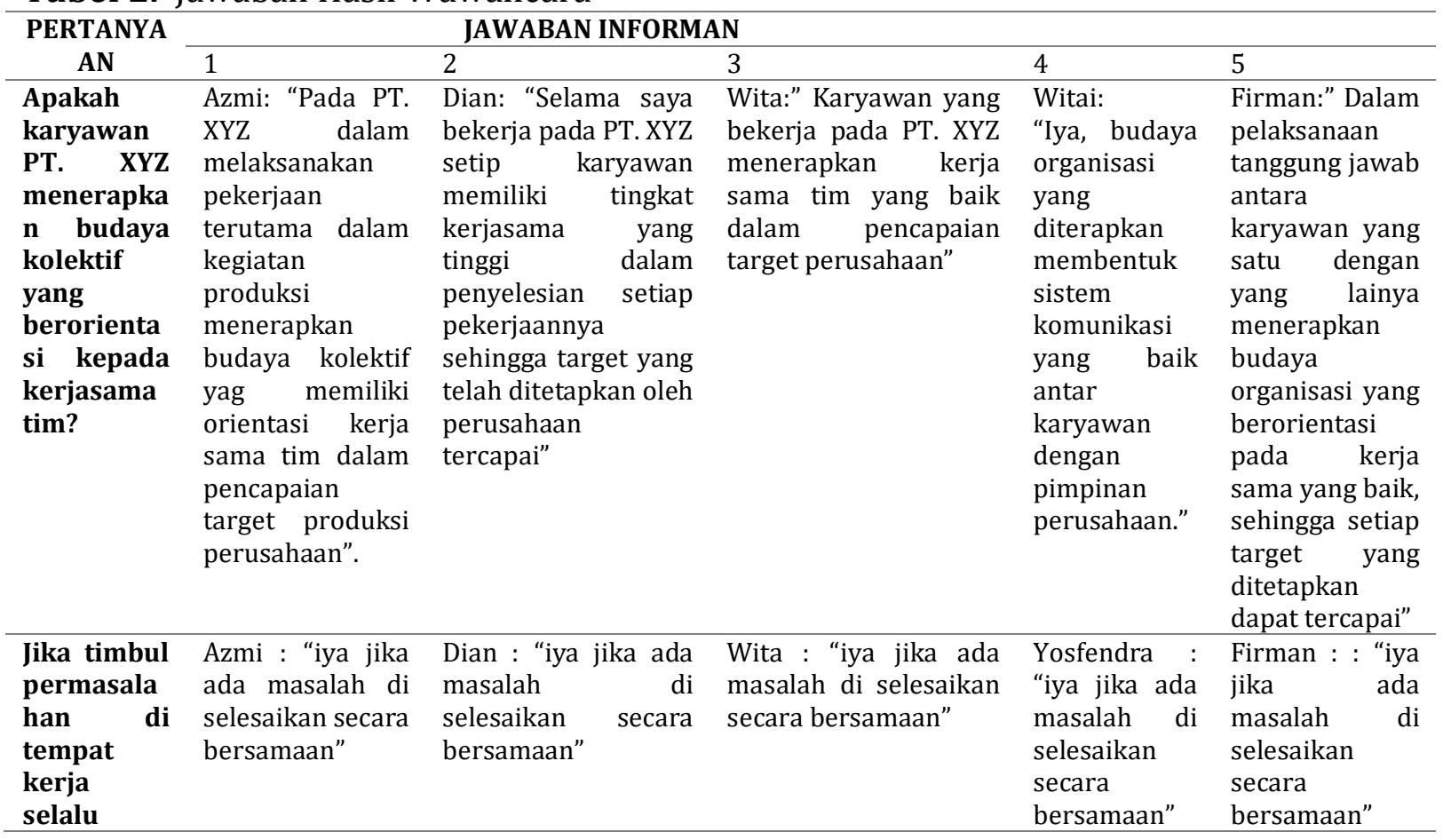




\begin{tabular}{|c|c|c|c|c|c|}
\hline $\begin{array}{l}\text { diselesaika } \\
\text { n bersama- } \\
\text { sama. }\end{array}$ & & & & & \\
\hline $\begin{array}{l}\text { Setiap } \\
\text { bekerja } \\
\text { saya lebih } \\
\text { mengutam } \\
\text { akan } \\
\text { terhadap } \\
\text { pelayanan } \\
\text { umum } \\
\text { daripada } \\
\text { kepentinga } \\
\text { n pribadi/ke } \\
\text { lompok. }\end{array}$ & $\begin{array}{l}\text { Azmi " selama } \\
\text { saya bekerja, } \\
\text { saya lebih } \\
\text { mengutaakan } \\
\text { kepentingan } \\
\text { pribadi atau } \\
\text { kelompok" }\end{array}$ & $\begin{array}{l}\text { Dian :" saya lebih } \\
\text { mengutamakan } \\
\text { kepentingan pribadi } \\
\text { atau kelompok" }\end{array}$ & $\begin{array}{l}\text { Wita :"menurut saya } \\
\text { kepentingan pribadi } \\
\text { atau kelompok yg } \\
\text { harus } \\
\text { diutamakan" lebih }\end{array}$ & $\begin{array}{l}\text { Yosfendra :" } \\
\text { saya } \\
\text { mengutamak } \\
\text { an } \\
\text { kepentingan } \\
\text { pribadi atau } \\
\text { kelompok } \\
\text { terlebih } \\
\text { dahulu" }\end{array}$ & $\begin{array}{l}\text { Firman } \\
\text { :"kepentingan } \\
\text { pribadi atau } \\
\text { kelompok yang } \\
\text { lebih saya } \\
\text { utamakan" }\end{array}$ \\
\hline $\begin{array}{l}\text { Apakah } \\
\text { adanya } \\
\text { sistem } \\
\text { atasan dan } \\
\text { bawahan } \\
\text { yang } \\
\text { kental } \\
\text { pada } \\
\text { perusahaa } \\
\text { n? }\end{array}$ & $\begin{array}{l}\text { Azmi: "Pada PT. } \\
\text { XYZ dalam } \\
\text { melaksanakan } \\
\text { pekerjaan dan } \\
\text { dalam } \\
\text { menjalankan } \\
\text { aktivitas sehari- } \\
\text { hari perusahaan } \\
\text { tidak sistem atasan } \\
\text { menerapkan } \\
\text { dan bawahan } \\
\text { namun saling } \\
\text { perusahaan } \\
\text { menerapkan } \\
\text { sistem setiap } \\
\text { merangkul } \\
\text { dalam pam salan } \\
\text { persoalan yang } \\
\text { dihadapi oleh } \\
\text { perusahaan ". }\end{array}$ & 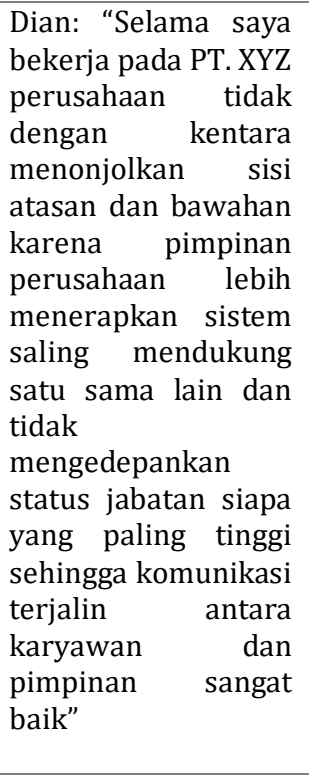 & \begin{tabular}{lr}
\multicolumn{2}{l}{ Wita:" PT. XYZ tidak } \\
menonjolkan & sistem \\
atasan dan & bawahan \\
karena & gaya \\
kepemimpinan & yang \\
diterapkan & oleh \\
pimpinan & sangat \\
merangkul & \\
bawahannya & dalam \\
pelaksanaan & kegiatan \\
operasionaL & \\
perusahaan" &
\end{tabular} & $\begin{array}{l}\text { Yosfendra:" } \\
\text { Dalam } \\
\text { pelaksanaan } \\
\text { kegiatan } \\
\text { operasional } \\
\text { dan aktivitas- } \\
\text { aktivitas } \\
\text { lainya dalam } \\
\text { penyelesaian } \\
\text { pekerjaan PT. } \\
\text { XYZ tidak } \\
\text { menonjolkan } \\
\text { sistem atasan } \\
\text { dan bawahan } \\
\text { sehingga } \\
\text { antara atasan } \\
\text { dan bawahan } \\
\text { terjalin } \\
\text { komunikasi } \\
\text { yang sangat } \\
\text { baik" }\end{array}$ & $\begin{array}{l}\text { Firman:" PT. } \\
\text { XYZ tidak } \\
\text { menonjolkan } \\
\text { sistem atasan } \\
\text { dan bawahan } \\
\text { karena gaya } \\
\text { kepemimpinan } \\
\text { yang } \\
\text { diterapkan oleh } \\
\text { pimpinan } \\
\text { sangat } \\
\text { merangkul } \\
\text { bawahannya } \\
\text { dalam } \\
\text { pelaksanaan } \\
\text { kegiatan } \\
\text { operasionaL } \\
\text { perusahaan" }\end{array}$ \\
\hline $\begin{array}{l}\text { Mampu } \\
\text { membina } \\
\text { hubungan } \\
\text { yang baik } \\
\text { dengan } \\
\text { karyawan } \\
\text { dalam } \\
\text { konteks } \\
\text { pribadi } \\
\text { maupun } \\
\text { dalam } \\
\text { lingkup } \\
\text { hubungan } \\
\text { kerja. }\end{array}$ & $\begin{array}{lr}\text { Azmi } & \text { :"iya } \\
\text { mampu,, untuk } & \text { unenjalin } \\
\text { mubungan } & \text { baik } \\
\text { halam } & \\
\text { dalan } & \\
\text { lingkungan kerja } \\
\text { sangat } & \text { penting } \\
\text { karena } & \text { rekan } \\
\text { kerja } & \text { sama } \\
\text { seperti } & \text { keluarga } \\
\text { sendiri ryang } & \text { yamper setiap } \\
\text { hampertemu" }\end{array}$ & $\begin{array}{l}\text { Dian :"Iya mampu, } \\
\text { kerena jika kita } \\
\text { sudah bisa menjalin } \\
\text { hubungan baik } \\
\text { dalam lingkungan } \\
\text { kerja akan membuat } \\
\text { kita nyaman untuk } \\
\text { bekerja" }\end{array}$ & 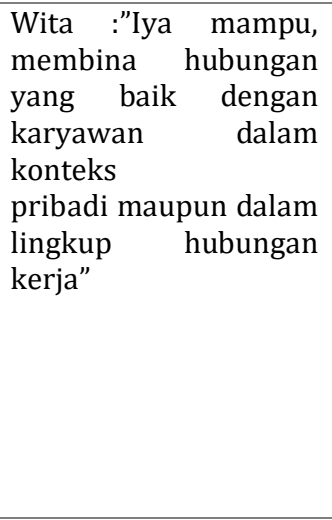 & $\begin{array}{l}\text { Yosfendra } \\
\text { :"Iya mampu, } \\
\text { Karena } \\
\text { membina } \\
\text { hubungan } \\
\text { dengan } \\
\text { karyawan } \\
\text { dilingkungan } \\
\text { kerja sangat } \\
\text { penting" }\end{array}$ & $\begin{array}{l}\text { Firman :" Iya } \\
\text { mampu, } \\
\text { membina } \\
\text { hubungan yang } \\
\text { baik dengan } \\
\text { karyawan } \\
\text { dalam konteks } \\
\text { pribadi } \\
\text { maupun dalam } \\
\text { lingkup } \\
\text { hubungan } \\
\text { kerja" }\end{array}$ \\
\hline $\begin{array}{l}\text { Pimpinan } \\
\text { saya selalu } \\
\text { mendengar } \\
\text { kan } \\
\text { pendapat } \\
\text { bawahann } \\
\text { ya. }\end{array}$ & $\begin{array}{l}\text { Azmi :" Iya, } \\
\text { Pimpinan saya } \\
\text { selalu terbuka } \\
\text { untuk } \\
\text { mendengarkan } \\
\text { pendapat } \\
\text { bawahannya" }\end{array}$ & $\begin{array}{l}\text { Dian :" Iya, Pimpinan } \\
\text { saya selalu } \\
\text { memberikan } \\
\text { kesempatan untuk } \\
\text { mendengarkan } \\
\text { pendapat } \\
\text { bawahannya" }\end{array}$ & $\begin{array}{l}\text { Wita :" Iya, Pimpinan } \\
\text { saya } \\
\text { mendengarkan } \\
\text { pendapat } \\
\text { bawahannya" }\end{array}$ & $\begin{array}{l}\text { Yosfendra :" } \\
\text { Iya, Pimpinan } \\
\text { saya selalu } \\
\text { bersedia } \\
\text { untuk } \\
\text { mendengarka } \\
\text { n pendapat } \\
\text { bawahannya" }\end{array}$ & $\begin{array}{l}\text { Firman :" Iya, } \\
\text { Pimpinan saya } \\
\text { selalu } \\
\text { mendengarkan } \\
\text { pendapat } \\
\text { bawahannya" }\end{array}$ \\
\hline $\begin{array}{l}\text { Apakah } \\
\text { Budaya } \\
\text { Organisasi } \\
\end{array}$ & $\begin{array}{lc}\text { Azmi: } & \text { Iya, } \\
\text { budaya } & \\
\text { organisasi } & \text { yang } \\
\end{array}$ & $\begin{array}{lr}\text { Dian: Iya, } & \text { budaya } \\
\text { organisasi } & \text { yang } \\
\text { diterapkan } & \\
\end{array}$ & $\begin{array}{l}\text { Wita: Iya, } \\
\text { organisasi } \\
\text { diterapkan }\end{array}$ & $\begin{array}{l}\text { Yosfendra: } \\
\text { Iya, budaya } \\
\text { organisasi }\end{array}$ & $\begin{array}{l}\text { Firman: Iya, } \\
\text { budaya } \\
\text { organisasi } \\
\end{array}$ \\
\hline
\end{tabular}




\begin{tabular}{|c|c|c|c|c|c|}
\hline $\begin{array}{l}\text { yang } \\
\text { diterapkan } \\
\text { oleh PT. XY } \\
\text { memperla } \\
\text { ncar } \\
\text { proses } \\
\text { Komunikas } \\
\text { i antar } \\
\text { karyawan? }\end{array}$ & $\begin{array}{l}\text { diterapkan } \\
\text { memperlancar } \\
\text { komunikasi } \\
\text { antar karyawan } \\
\text { dalam } \\
\text { melaksanakan } \\
\text { pekerjaan. }\end{array}$ & $\begin{array}{l}\text { memperlancar } \\
\text { komunikasi antar } \\
\text { karyawan dalam } \\
\text { melaksanakan } \\
\text { pekerjaan }\end{array}$ & $\begin{array}{lr}\text { memperlancar } & \\
\text { komunikasi } & \text { antar } \\
\text { karyawan } & \text { dalam } \\
\text { melaksanakan } & \\
\text { pekerjaan. } & \end{array}$ & $\begin{array}{l}\text { yang } \\
\text { diterapkan } \\
\text { memperlanca } \\
\text { r komunikasi } \\
\text { antar } \\
\text { karyawan } \\
\text { dalam } \\
\text { melaksanaka } \\
\text { n pekerjaan }\end{array}$ & $\begin{array}{l}\text { diterapkan } \\
\text { memperlancar } \\
\text { komunikasi } \\
\text { antar karyawan } \\
\text { dalam } \\
\text { melaksanakan } \\
\text { pekerjaan }\end{array}$ \\
\hline $\begin{array}{l}\text { Apakah } \\
\text { Budaya } \\
\text { organisasi } \\
\text { yang } \\
\text { diterapkan } \\
\text { oleh PT. } \\
\text { XYZ dapat } \\
\text { membentu } \\
\text { k } \\
\text { komunikas } \\
\text { i yang baik } \\
\text { dengan } \\
\text { karyawan } \\
\text { maupun } \\
\text { pimpinan } \\
\text { PT. XYZ? }\end{array}$ & $\begin{array}{l}\text { Azmi: Iya, } \\
\text { budaya } \\
\text { organisasi yang } \\
\text { diterapkan } \\
\text { membentuk } \\
\text { sistem } \\
\text { komunikasi yang } \\
\text { baik dengan } \\
\text { karyawan } \\
\text { maupun } \\
\text { pimpinan } \\
\text { perusahaan. }\end{array}$ & $\begin{array}{lr}\begin{array}{l}\text { Dian: Iya, } \\
\text { organisasi }\end{array} & \text { budaya } \\
\text { diterapkang } & \\
\text { membentuk } & \text { sistem } \\
\text { komunikasi } & \text { yang } \\
\text { baik } & \text { dengan } \\
\text { karyawan } & \text { maupun } \\
\text { pimpinan } & \\
\text { perusahaan. } & \end{array}$ & $\begin{array}{lr}\text { Wita: Iya, } & \text { budaya } \\
\text { organisasi } & \text { yang } \\
\text { diterapkan } & \\
\text { membentuk } & \text { sistem } \\
\text { komunikasi } & \text { yang baik } \\
\text { dengan } & \text { karyawan } \\
\text { maupun } & \text { pimpinan } \\
\text { perusahaan. } & \end{array}$ & $\begin{array}{l}\text { Yosfendra: } \\
\text { Iya, budaya } \\
\text { organisasi } \\
\text { yang } \\
\text { diterapkan } \\
\text { membentuk } \\
\text { sistem } \\
\text { komunikasi } \\
\text { yang baik } \\
\text { dengan } \\
\text { karyawan } \\
\text { maupun } \\
\text { pimpinan } \\
\text { perusahaan. }\end{array}$ & $\begin{array}{l}\text { Firman: Iya, } \\
\text { budaya } \\
\text { organisasi yang } \\
\text { diterapkan } \\
\text { membentuk } \\
\text { sistem } \\
\text { komunikasi } \\
\text { yang baik } \\
\text { dengan } \\
\text { karyawan } \\
\text { maupun } \\
\text { pimpinan } \\
\text { perusahaan. }\end{array}$ \\
\hline
\end{tabular}

\section{Pembahasan}

Didasarkan pada cakupan sumber daya manusia (SDM) yang dimiliki oleh sebuah perusahaan untuk mendapatkan karyawan yang memiliki tingkat keprofesionalan yang sesuai dengan yang diharapkan oleh sebuah perusahaan agar nantinya dapat memberikan kontribusi yang lebih pada perusahaan. Dengan adanya harapan yang tinggi yang nantinya dimiliki oleh seorang karyawan maka sebuah perusahaan memerlukan sebuah pedoman dalam pelaksanaan kerja yang nantinya dilakukan oleh karyawan yang bekreja pada perusahaan mereka yaitu budaya organisasi yang dijalankan oleh perusahaan dalam pelaksanaan setiap pekerjaan yang ada pada perusahaan. Dengan adanya budaya organisasi tersebut diharapkan dapat menjadi acuan yang secara sistematis dapat mmeberikan tuntunan kepada karyawan dalam melaksanakan setiap pekerjaannya baik itu acuan dalam melakukan komunikasi maupun yang lainnya. Didasarkan pada temuan yang didapatkan dari karyawan PT. XYZyang menjadi sampel dari penelitian yang dilakukan dimana bahwasannya setiap karyawan yang bekerja pada perusahaan tersebut diharuskan untuk mengikuti setiap budaya organisasi yag telah diterapkan oleh perusahaan tersebut pada pelaksanaan pekerjaan yang mereka lakukan. 
"Suyanto, 2007: 217 mendefinisikan budaya organisasi selaku program pemikiran secara kolektif yang membedakan para anggota suatu organisasi dari organisasi yang lain.Budaya organisasi mempunyai pengaruh yang kuat terhadap perilaku karyawan.Budaya organisasi ini dapat membentuk lingkungan yang destruktif ataupun konstruktif dalam sebuah perusahaan sehingga meningkatkan kinerja karyawan serta kenyamanan dalam bekerja (Safaria, 2004:9). Pengaruh budaya organisasi pada PT. XYZ sangat lah penting untuk di utamakan. Hasil wawancara mengenai pembinaan hubungan baik dalam konteksk pribadi maupun lingkup kerja, semua infoman merasa bawa meman sangat sangat penting untuk membina hubungan yang baik dalam hubungan rekan kerja karena rekan kerja sudah di anggap seperti keluarga yang hampir setiap hari bertemu dan bersama, dan ketika suatu hubungan rekan kerja sudah terjalin dengan baik maka suasana dalam lingkungan kerja pun akan terasa nyaman.

Bersumber dari berbagai pendapat para ahli, bisa disimpulkan kalau budaya organisasi ialah suatu nilai yang dianut oleh seluruh karyawan dalam suatu organisasi. Dimana setiap karyawan wajib menguasai ciri khas budaya organisasi diperusahaan, ciri khas dari suatu organisasi tersebut untuk mnendukung kinerja karyawan sehingga manfaat budaya organisasi sebagai aspek konstruktif suatu perusahaan ataupun organisasi dalam meningkatkan kinerja karena merasa nyaman dalam bekerja.

Didasarkan pada wawancara yang dilakukan kepada informan dapat disimpulkan bahwasannya budaya yang diterapkan oleh perusahaan ialah budaya tradisional berkelompok yang dikelompokkan kedalam bentuk umum yaitu memiliki kemampuan dalam melakukan kerjasamamerupakan hal terpenting yang dilakukan oleh setiap karyawan PT. XYZ. Pelaksanaan budaya oganisasi yang diterapkan oleh PT. XYZmemberikan gambaran bahwasannya budaya yang diterapkan adalah berbasis pada budaya kelompok kolektif yang dapat menunjang tercapainya dari tujuan perusahaan atau organisasi, dimana hal tersebut dapat dilihat dari hasil pengukuran atas indikator orientasi pada tim dimana hal tersebut mencakup aktivitas atau pelaksanaan kerja yang dilakukan oleh karyawan PT. XYZ yang dinilai cukup baik dalam hal melaksanakan kerja tim, hal tersebut menunjukkan pelaksanaan dari budaya organisasi telah menunjang dari 
penigkatan kualitas kerja sama tim yang dilakukan oleh karyawan dalam pelaksanaan kerjanya. Budaya organisasi yang didefinisikan oleh Edgar H. Schein (dalam Tangkilisan, 2007:15) ialah selaku pola asumsi dasar bersama yang dipelajari oleh kelompok dalam suatu organisasi sebagai alat dalam memecahkan permasalah terhadap penyesuaian aspek eksternal dan integrasi aspek internal, serta telah teruji sahih, serta berikutnya diajarkan kepada para anggota organisasiyang baru sebagai cara untuk mempersepsikan, memikirkan, serta merasakan dalam kaitannya dengan permasalah yang dialami. Seperti yang dituturkan oleh seorang informan:

"Azmi: Pada PT. XYZ dalam melaksanakan pekerjaan terutama dalam kegiatan produksi menerapkan budaya kolektif yaag memiliki orientasi kerja sama tim dalam pencapaian target produksi perusahaan"

Dari adanya temuan tersebut juga memberikan indikasi bahwsannya karyawan memiliki kesepakatan bahwasannya kerjasama yang dilakukan secara team sangat penting dilakukan dalam pencapaian tujuan maupun pelaksanaan taggung jawab yang mereka miliki sehingga degan adanya hal tersebut setiap persoalan dan pekerjaan dapat terselesaiakan dengan tepat dan cepat. Hal tersebut juga dikemukakan oleh karyawan pada divisi atau bagian produksi PT. XYZ dimana hal tersebut dilakukan dengan tujuan untuk mencapai target yang telah ditetapkan. Sehingga denga adanya kerjasama tim yang baik dan saling mendukung satu sama lain dapat mempercepat pencapaian target produksi yang telah ditetapkan oleh perusahaan. Dengan adanya hal itu menjalin solidaritas antar karyawan baik itu mencakup dalam ruang lingkup pekerjaan maupun nantinya diluar pekerjaan. Karena mereka telah terbiasa menyelesaikan setiap pekerjaan secara tim atau bersama-sama. Didasarkan pada masalah tersebut maka peneliti dapat menarik kesimpulan bahwasannya kerja tim dalam budaya organisasi sangatlah penting diterapkan untuk membangun hubungan yang baik antar sesama karyawan dalam lingkup pekerjaan maupun diluar pekerjaan.

Budaya organisasi yang kedua adalah tidak adanya atasan dan bawahan dalam pelaksanaan pekerjaan. Dimana hal tersebut diberlakukan untuk karyawan yang baru lulus atau kategori freshgraduet dimana karyawan dididik dengan level pekerjaan yang paling rendah untuk menanamkan kemandirian dalam diri karyawan dimana nantinya 
agar tidak memiliki masalah ketika menghadapi tingkat pekerjaan yang lebih tinggi. Karena sebaik apapun tingkat kualitas yang dimiliki oleh seorang karyawan haruslah tetap belajar dari hal pekerjaan yang berada dilevel bawah pada profesi yang dibidanginya.Sehingga dengan adanya hal seperti itu karyawan dapat mengenal sistem yang diterapkan oleh perusahaan sehingga nantinya terbiasa dengan temuan-temuan masalah yang dilalui dalam pelaksanaan pekerjaan.Didasarkan pada temuan yang ada pada PT. XYZ ditemui bahwasanya karyawannya memiliki kesepakatan bahwa budaya tersebut pentig untuk diterapkan pada perusahaan untuk memberikan arahan pada setiap pekerjaan yang dilakukan sehingga nantinya pada setiap pelaksanaan pekerjaan yang mereka lakukan menjadi terarah. Seperti yang dituturkan oleh salah seorang informan bahwasannya:

"Dian: Selama saya bekerja pada PT. XYZ perusahaan tidak dengan kentara menonjolkan sisi atasan dan bawahan karena pimpinan perusahaan lebih menerapkan sistem saling mendukung satu sama lain dan tidak mengedepankan status jabatan siapa yang paling tinggi sehingga komunikasi terjalin antara karyawan dan pimpinan sangat baik"

Budaya organisasi yang ketiga yaitu sebuah perusahaan berlangsung seumur hidup. Didasarkan pada hasil wawancara yang dilakukan terhadap informan maka dapat disimpulkan budaya tersebut memberikan gambaran dan pesan kepada karyawan bahwasannya tempat bekerja yang dimiliki sekrang merupakan rumah yang mereka miliki seumur hidup mereka.Sehingga dengan adanya hal tersebut mereka memiliki tanggung jawab dalam memmepertahankan kelangsungan hidup perusahaan dengan memberikan kontribusi terbaik yang mereka miliki.Sehingga nantinya perusahaan dapat bertahan menghadapi setiap persaingan yang ada pada dunia global.Selain itu perusahaan juga memiliki kewajiban dalam memberikan pelatihan yang merupakan program investasi pada karyawan sehingga dapat mengupgrade pengetahuan yang dimiliki oleh karyawan.Hal tersebut dilakukan karena karyawan merupakan salah satu aset yang dimiliki oleh sebuah perusahaan yang harus dikembangkan kemampuannya sehingga dapat memberikan kinerja terbaik untuk perusahaan.sesuai yang dituturkan oleh salah seorang informan:

"Firman: Menurut saya tempat saya bekerja merupakan suatu hal yang saya miliki yang harus saya jaga keberlangsungan dan memberikan yang terbaik agar perusahaan tempat 
saya bekerja memiliki kinerja yang baik sehingga nantinya juga akan berpengaruh pada gaji yang saya peroleh"

Pengaruh budaya organisasi terhadap komunikasi yang dimiliki oleh seorang karyawan sangatlah berpengaruh. Karena dengan adanya budaya organisasi yang menjadi acuan atau panduan terhadap karyawan dalam pelaksaaan tugasnya maka akan tercipta komunikasi yang baik dalam tim sehingga kerjasama yang mereka lakukan dapat terbentuk dengan baik. Dengan adanya hal tersebut nantinya dapat meingkatkan kinerja atau kontribusi mereka pada perusahaan tempat mereka bekerja dan mengabdikan diri mereka.Didasarkan pada hasil wawancara yang dilakukan dengan informan maka dapat disimpulkan bahwasannya budaya organisasi yang diterapkan oleh sebuah perusahaan membentuk komunikasi yang ada pada karyawan PT. XYZ. Hal ini sesuai dengan hasil wawancara yang dituturkan oleh salah seorang informan:

"Dian: Iya, Iya, budaya organisasi yang diterapkan memperlancar komunikasi antar karyawan dalam pelaksanaan pekerjaan"

Dimana hasil dari penelitian ini sejalan dengan hasil penelitian yang sebelumnya telah dilaksanakan oleh Akbar (2015) dan Sismona (2015) dimana menurut hasil penelitian yang mereka lakukan tanpa danya budaya organisasi yang tepat maka tidak akan menghasilkan komunikasi yang baik antar karyawan iini memberikan gambaran bahwasannya dengan adanya budaya organisasi yang baik yang diterapkan oleh sebuah perusahaan akan memberikan pengaruh terhadap komunikasi yang terjadi antar karyawannya. Pada perusahaan, komunikasi organisasi memiliki sebuah peranan yang sangat vital dan penting, hal tersebut sagat berlaku dalam pengefektifitasan setiap kegiatan yang dilakukan pada organisasi begtu juga dengan apa yang ada pada PT. XYZ. dimana budaya organisasi dan proses komunikasi merupakan seuah sarana yang daat memberikan koordinasi dan arahan kepada karawan dalam pelaksanaan tugasnya, Sehingga dari sekian banyak presepsi yang ada dan berbeda pada setiap karyawan dapat menjadi satu tujuan dalam mencapai target maupun tujuan yang telah ditetapkan oleh organisasi.

Dengan adanya pengaruh yang diberikan oleh budaya organisasi terhadap komunikasi karyawan dalam pelaksanaan kerjanya pada PT. XYZ yang terjadi ketika antar karyawan 
melakukan interaksi dengan karyawan lainnya yang dilakukan secara keberlanjutan sehingga terjalinnya sebuah kerjasama yang baik dalam pencapaian tujuan perusahaan.Sehigga dengan begitu dapat membentuk sebuah acuan maupun sebuah pedoman dalam mebuat atau mengambil sebuah keputusan melakui indikator-indikator yang digunakan dalam penelitian ini yang dapat memberikan informasi yang jelas dan menghindari kesalahfahaman atas penyampaian dan penerimaan informasi pada karyawan.Dimana dalam hasil temuan pada PT Semen Padang meiliki tingkat komunikasi yang baik.Baik itu yang berlangsung anatara karyawan dengan sesama karyawan maupun antara karyawan dengan atasan atau pimpinanya.Hal tersebut menunjukkan dengan adanya penerapan budaya organisasi yang tepat dan karyawan juga mengerti dan faham atas budaya yang dilaksanakan atau diterapkan pada perusahaan telah menunjang pelaksanaan komunikasi yang baik antar sesama baik itu karyawan maupun atasan yang bekerja pada PT. XYZ. Hal tersebut terlihat dari adanya ketercapaian target melalui sistem kerjasama yang baik dan proses komunikasi yang baik disetiap karyawan PT. XYZ.

Berdasarkan hal tersebut memperlihatkan bahwannya budaya organisasi memberikan pengaruh terhadap komunikasi karyawan pada PT. XYZ karena apabila budaya organisasi tidak dipertahankan oleh perusahaan maka komunikasi yang terjalin juga akan mengalami penurunan. sehingga nantinya juga akan memperburuk kinerja karyawan yang berakibat pada tidak tercapainya tujuan yang telah ditetapkan oleh perusahaan. Sehingga sangat penting untuk ditekankan agar setiap karyawan memahami setiap budaya organisasi yang diterapkan oleh perusahaan sekaligus menerapkannya dalam pelaksanaan tugas dan tanggung jawab yang mereka miliki sehingga nantinya tidak terjadi kesalahan-kesalahan dalam pelaksanaan atau dalam mengerjakan job desk yang mereka miliki. Karena jika salah satu karyawan melakukan kesalahan berupa kesalahan dalam penerimaa informasi dari proses komunikasi yang dilakukan maka akan berimbas kepada karyawan lainnya, sehingga nantinya akan terjadi berupa miss komunikasi pada setiap proses pelaksanaan tugas dan tanggung jawab.

Keberpengaruhan antara budaya organisasi dengan komunikasi karyawan juga terliat pada yaitu ketika satu karyawan megalami kesalahan atau menemui suatu masalah dalam 
pelaksanaan kerjaanya maka karyawan lain akan mengajak karyawan tersebut untuk berdiskusi dan mencari soulsi dari permasalahan yang ada sehingga nantinya ditemukan solusi yang tepat untuk mengatasi masalah yang ada. Sehingga karyawan tidak hanya memikirkan masalahnya sendiri namun dibantu oleh rekannya yang lain sehingga diantara mereka terjalin solidaritas yang kuat. Dan hal tersebut tidak hanya berlangsung dalam cakupan lingkungan kerja saja namun juga berlangsung pada lingkungan diluar kerja.hal tersebut sangat berguna untuk karyawan dan perusahaan karena hal tersebut telah mencerminkan bahwasannya telah tercipta rasa kekeluargaan pada perusahaan sehingga suatu masalah yang terjadi pada perusahaan akan diselesaikan secara bersamasama dan dicari solusinya secara bersama-sama sehingga di dalam perusahaan tidak ada yang namyan karyawan yang bersifat egois dan individualis.

\section{Kesimpulan}

Didasarkan pada hasil temuan dan hasil analisis terhadap data-data yang diperoleh peneliti dalam penelitian ini maka dapat ditarik kesimpulan pada penelitian ini yaitu bahwasannya budaya organisasi yang diterapkan oleh PT. XYZ dalam pelaksanaan kegiatan operasional dan pelaksanaan kerja oleh karyawannya memiliki hubungan dalam membentuk komunikasi karyawan dalam pelaksanaan kerja pada PT. XYZ, Hal tersebut didasarkan pada indikator-indikator yang diterapkan dalam penelitian ini,. Sehingga dengan adanya hal tersebut maka peneliti memberikan penyaranan terhadap PT. XYZ mengenai budaya organisasi yang diterapkan pada perusahaan sudah tergolong dan mendekati kata baik yang harus selalu dpertahankan oleh perusahaan melalui pemberian contoh yang baik dari pimpinan terhadap karyawan yang ada sehingga nantinya karyawan yang bekerja pada PT. XYZ juga memiliki tingkat keloyalan yang tinggi. Kemudian perusahaan harus selalu menjalankan setiap budaya organisasi sehingga dapat menunjang komunikasi antar karywan sehingga terjalin kerja sama yang sangat baik antar karyawan. Karena dengan begitu nantinya akan tercipta kinerja yang yang dapat memberikan kontribusi terhadap perusahaan.

\section{Referensi :}

Akbar, M. A. (2015). Pengaruh Gaya Kepemimpinan Transformasional dan Komunikasi Organisasi Terhadap Kinerja Karyawan: Studi pada Karyawan Bank Jatim Cabang 
Malang,. Jurnal Administrasi Bisnis (JAB).

Awadh dan Saad. (2013). Impact of Organizational Culture on Employee Performance. International Review of Management and Business Research, 2(1), 2306-9007.

Dewi, L. (2012). Analisis Pengaruh Kepemimpinan dan Budaya Organisasi Terhadap Kinerja Pegawai dengan Sistem Reward Sebagai Variabel Moderating. Jurnal Fakultas Ekonomi Universitas Airlangga.

Henry, S. (2012). Manajemen Sumber Daya Manusia. Bumi Aksara.

Mahboobeh, G. (2013). The Impact of "Organizational Culture" on "Job Satisfaction" and "Employee Performance." Evidence From Commercial Banks of the Pune City, 7, 386397.

Nia Septiana, P. (2014). Komunikasi Organisasi dalam Mensosialisasikan Budaya Organisasi Prinsip 46 Pt. Bank Negara Indonesia (Persero)Tbk. Kantor Cabang Utama Samarinda. E-Journal Komunikasi, 2(2), 285-399.

Prabawa. (2013). Pengaruh Komunikasi Organisasi dan Gaya Kepemimpinan Terhadap Kinerja Karyawan dengan Budaya Organisasi Sebagai Variabel Intervening: Studi Kasus pada PT. TWC Borobudur, Prambanan. Jurnal Universitas Gajah Mada.

Rizza Muhammad, A. (2013). Pengaruh Budaya Organisasi Terhadap Employee Engagement (Studi Pada Karyawan PT. Primatexco Indonesia di Batang). Journal of Science and Industrial Psychology, 2(1), 2252-6838.

Safaria, Triantoro. 2004. Kepemimpinan. Yogyakarta: Penerbit Graha Ilmu

Sari, T. K. (2013). Pengaruh Budaya Organisasi Terhadap Komitmen Organisasi Melalui Kepuasan Kerja Karyawan. Jurnal Ilmu Manajemen, 1, 3. 